\title{
A DILEMMA IN UPPER SECONDARY TEACHER EDUCATION
}

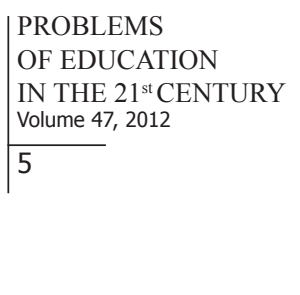

\author{
Muammer Çalık \\ Karadeniz Technical Unıversity, Turkey \\ E-mail: muammer38@hotmail.com
}

There is a consensus about primary and lower secondary teacher education in that Faculty of Education is actively responsible for preparing them for their future teaching careers. However, a struggle between Faculty of Science and Faculty of Education has still been continuing to come up with an agreement for upper secondary teacher education. For example, the undergraduate students attend subject matter courses in Faculty of Science and then take pedagogical (content knowledge) courses in Faculty of Education at most of the developed countries, i.e. USA, Germany, England. Despite the fact that this program seems to have been time efficient for pedagogical courses, this has lacked of motivating them to become the upper secondary teachers. In fact, motivation and enthusiasms to be a teacher play a significant role to learn how to teach.

On the other hand, a combined (blended) upper secondary teacher education is available in developing countries, i.e. Turkey. Moreover, the undergraduate students from Faculty of Science may also attend a short-time weekend courses and get teacher training certificate in such countries. Unfortunately, this type of short alternative way to be an upper secondary teacher has arised a mission confusion between Faculty of Science and Faculty of Education. For instance, Faculty of Science's mission still possesses very dominant idea 'if someone knows subject matter knowledge, (s) he transmits this knowledge to the students as well'. Indeed, its mission does not include supplying the upper secondary teacher education because they principally concentrate on educating scientists concerning specific research areas. That is, the undergraduate students from Faculty of Science generally see this issue as a second chance to become the upper secondary teachers. For this reason, prior to decision making of upper secondary teacher education, competencies of the faculties and their patterns should be checked.

Even though the students at upper secondary teacher education spend much more time with subject matter courses taught by the lecturers at Faculty of Science - whatever type of the foregoing models is tracked, Faculty of Education is generally blamed by the teacher quality if a lack of teaching competency in upper secondary teachers appears. Let's start to identify teacher competencies and stakeholders from different countries in Problems of Education in the $21^{\text {st }}$ Century Journal. Later on, why don't we discuss who is responsible for the upper secondary teacher education. Indeed, we now have this journal as a correct place to do the foregoing issues.

Received: October 23, 2012

Accepted: November 02, 2012

$\begin{array}{ll}\text { Muammer Çalik } & \text { PhD, Associate Professor of Chemistry Education, Karadeniz Technical Uni- } \\ & \text { versity, Fatih Faculty of Education, Department of Primary Teacher Education, } \\ & \text { Trabzon, Turkey. } \\ & \text { E-mail: muammer38@hotmail.com } \\ & \text { Website: http://ktu.academia.edu/MUAMMERCALIK }\end{array}$

